GRIPS Discussion Paper 16-07

\title{
Global Value Chains and New Thinking on Trade and Industrial Policy
}

\author{
Yuqing Xing
}

June 2016

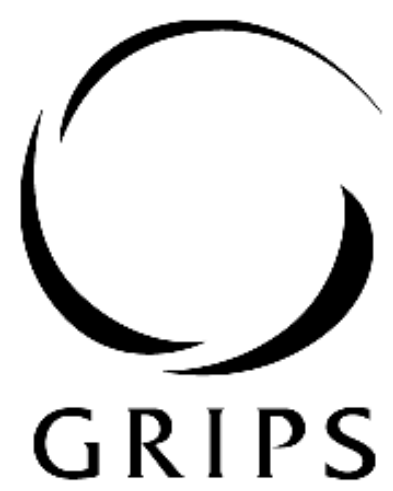

National GRADUATE INSTITUTE

FOR POLICY STUDIES

National Graduate Institute for Policy Studies

7-22-1 Roppongi, Minato-ku,

Tokyo, Japan 106-8677 


\section{Global Value Chains and New Thinking on Trade and Industrial Policy}

Yuqing Xing

National Graduate Institute for Policy Studies

7-22-1 Roppongi, Minato-Ku

Tokyo, Japan

Email: yuqing xing@grips.ac.jp

Abstract:

This paper argues that global value chains (GVCs) have transformed bilateral trade relations into multilateral and value added approach is needed to accurately measure the contribution of trade to economic growth and bilateral trade balances. Under GVCs, the impact of exchange rates on bilateral trade balances have been weakened and technological innovations may not necessarily increase domestic employment. The challenges associated with the emergence of GVCs require an indepth understanding of modern international trade, which in turn calls for new modes of thinking and new theories. For developing countries, focusing on specific segments of GVCs and upgrading industrial capacity along value chains could be an alternative path of industrialization.

JEL: F1 


\section{Introduction}

Unlike the US, China remains a labor abundant country and clearly has no comparative advantage in the production of either capital-intensive or technologyintensive products. Nevertheless, China has a huge trade surplus with the US, not only in labor-intensive products, but also in high-tech products. According to the US Census Bureau (2011), in 2010 the US had a US\$94 billion trade deficit with China in advanced technology products. Take for example that trendiest of high-tech gadgets, the iPhone: all iPhones sold in the US market are actually imported from China. That one product accounted for $\$ 1.9$ billion of the 2009 US trade deficit in bilateral trade (Xing and Detert, 2010). The prevailing pattern of China-US trade in high-tech products seems to contradict classic comparative advantage theory, which would predict that China would import high-tech products from the US, and not vice versa.

Despite three and half decades of rapid growth, China is still at the catching-up stage, having just achieved middle-income country status. The GDP per capita of China is far less than that of developed countries. There are few industries where Chinese indigenous firms are world leaders. Trade statistics on global high-tech trade, on the other hand, present an unexpected phenomenon: China has surpassed the US, Japan and $27 \mathrm{EU}$ countries, emerging as the top high-tech exporting nation (Meri, 2009). Industrialized countries are now the main destinations for China's hightech exports.

To explain puzzles such as those seen in the iPhone trade and China's high-tech export dominance, it is necessary to turn away from classic comparative advantage theory as it relates to international trade and examine the fundamental changes in the organizations of international trade and their implications for trade patterns and national comparative advantage. Grossman and Rossi-Hansberg (2008) argue that today's trade is no longer clothes for wine; it differs significantly from the trade discussed by the British economist David Ricardo some 200 years ago. Modern international trade has evolved from trade in tasks to trade in goods. Almost all manufacturing products are now produced and traded along global value chains 
(GVCs), where many firms located in geographically dispersed countries are involved in tasks ranging from research and development to the final delivery of products to end users in the global market. Technological innovations and extensive outsourcing by multinational enterprises (MNEs) now direct and amplify trade flows, reshaping geographic trade patterns and balances.

GVCs involve complicated trade relationships between nations; they have transformed bilateral trade relationships into multilateral ones. In any GVC, firms from various countries jointly contribute to the value added of the final products. Export figures, measured as the gross value of goods crossing borders, tend to exaggerate the actual export capacity and technology advancement of the exporting nations. Current estimates of comparative advantage based on conventional trade statistics have significant biases and are no longer reliable indicators of national comparative advantage or competitiveness. Furthermore, an individual country participating in a GVC accounts for only a part of the entire value added of goods manufactured in that chain. The appreciation or depreciation of a country's currency should have a limited effect, impacting at most on the cost of tasks performed by that country's workers, not on the cost of tasks performed by firms in other countries. In that sense, GVCs mitigate the pass-through effect of exchange rates and limit the importance (in terms of trade balances) of an individual country's currency fluctuations.

The emergence of GVCs in the world economy has been bolstered by unprecedented globalization, changes in MNE strategy, and technological advances such as revolutionary technological innovation in information and communications, the backbone of international coordination, management and logistics. As multinational enterprises continue to slice the production process into relatively independent tasks and optimize production by allocating or outsourcing those tasks to geographically dispersed firms, developing countries encounter new opportunities to join the globalization phenomenon. By participating in GVCs established by MENs, firms from developing countries can overcome their capital and technology disadvantages and take part in the global market. Spillover from lead firms' 
intellectual property, such as technological innovations, brands and global distribution networks, enable firms from developing countries to benefit from the growth of international markets and generate opportunities for those firms to learn and move to higher ladders of value chains. The worldwide proliferation of GVCs, therefore, opens an alternative path to industrialization. China's success in the processing trade and Thailand's emergence as the Asian hub for the export of pickup trucks can be attributed in large part to their active participation in GVCs.

In this paper, I will briefly outline the primary changes in international trade resulting from the emergence of GVCs and the way in which developing countries could benefit from participating in GVCs. In particular, I will focus on new trade relationships under value chains, the need to measure trade in terms of value added, and new thinking regarding the nexus between trade and exchange rates. Further, to illustrate the mechanics of this new model of industrialization under GVCs, I will examine the successful experiences of China and Thailand.

\section{What are Global Value Chains?}

A global value chain is a sequential composite of the tasks necessary for the production of a product, from conception to delivery to end consumers in international markets, a process including research and development, product design, parts and components manufacturing, assembly and distribution. These tasks are carried out by firms in different countries (Gereffi and Karina, 2011). Depending on the governance structure, i.e. the identity of the managers and leaders of a value chain, a GVC can be classified as producer-driven or buyer-driven. Producer-driven chains are generally developed by technology leaders in capitalintensive industries such as the automobile, aircraft, computer, semiconductor industries. The automobile value chains led by Toyota and the electronics chains (iPod, iPhone and iPad) led by Apple are producer-driven value chains. Buyer-driven value chains are typically developed by large retailers and brand marketers, e.g., H\&M, GAP and Walmart (Gereffi, 1999). 
The most frequently cited example of a value chain is that of Apple's iPhone. The manufacture of the iPhone, which is at the technology frontier of mobile communication, involves a series of complex tasks. The product description on the back of each iPhone, "Designed by Apple in California. Assembled in China," declares unambiguously that iPhone is made neither in the US, nor in China, but rather in the world. The iPhone is designed and marketed by Apple, one of the most innovative US companies. Apart from software and product design, the production of iPhone components and assembly of iPhones takes place primarily outside the US. The manufacture of $3 G$ iPhones involves nine companies, located in China, Korea, Japan, Germany, and the US. The major producers and suppliers of iPhone parts and components include Toshiba, Samsung, Infineon, Broadcom, Numunyx, Murata, Dialog Semiconductor and Cirrius Logic. All iPhone components produced by these companies are shipped to Foxconn, a Taiwan-based company, for assembly into final products in Shenzhen, China and export to the global market. As the lead firm of the value chain, Apple sets the product standards, decides where to outsource the manufacturing tasks, and controls distribution and retailing through Apple stores as well agreements with mobile service providers in all target countries.

The total manufacturing cost of a $3 G$ iPhone (retail price US\$500) is US\$178.96, of which China accounts for US $\$ 6.5$, about $3.6 \%$ of total cost, Japan US $\$ 49.25$ (33.9\%), Korea US\$22.96 (12.8\%), Germany US\$30.15 (16.8\%), the US US\$10.75 $(6.0 \%)$ and the rest of the world US\$48.0 (26.8\%). The gross profit, i.e. the value added of Apple, is US\$321.4 per 3G iPhone, about $64 \%$ of total price (Xing and Detert, 2010). Assembly is the final stage of iPhone production, and since the launch of the first generation iPhone, Foxconn has been the exclusive assembler, so all ready-to-use iPhones available in the global market are shipped from China. Starting as a part of iPhone supply chains, China - the largest developing country - has emerged as the exclusive exporter of iPhones, even exporting iPhones to the US, where the iPhone was invented. 
Several main factors have contributed to the rapid development of GVCs in the last few decades. First, the manufacturing industry has disintegrated: advancements in production technologies have made it possible to break the production process into distinct segments which can be spread around the world. Additionally, the Internet and mobile communication technology have greatly reduced transaction costs and simplified the once-complex cross border coordination between firms. Regardless of geographic distance and time zones, buyers and suppliers along value chains can easily engage in real time communication and coordination. Furthermore, the advent of container shipping and improvements in logistics efficiency have lowered transportation costs and made it possible for intermediate goods, such as parts and components, to cross borders repeatedly. This unprecedented globalization, which has substantially eliminated tariff and non-tariff barriers, has also stimulated the proliferation of GVCs by facilitating the mobility of capital and the flow of goods. Finally, the operating strategies of MNEs have changed fundamentally, from producing most of the value in their products through internally integrated firms to specialization in core competencies. Outsourcing non-core tasks and production of parts and components to external firms has been adopted as common choice for profit maximization (Kaplinsky, 2013).

\section{New Thinking on Trade under GVCs}

\section{The complexity of trade relations}

Traditionally, exporting nations have been regarded as producers and importing countries as consumers. Trade relations between countries have been characterized as simply producer-consumer relationships; this is a dominant perception supporting mercantilism (the promotion of exports and the restriction of imports). Value chain based trade, quite distinct from the simple producer-consumer relationship, redefines the relationships between trading nations. Trade relations among countries involved in value chains have turned into partnerships. When countries import intermediate inputs such as parts and components from countries located downstream in value chains, those imports constitute necessary inputs of the exports or prerequisites for finishing tasks allocated by lead firms of GVCs. In other 
words, without the imports, it is impossible to produce the exports and fulfill the tasks. Now, rather than simple producer-consumer relations, trade flows reflect the division of labor in tasks and cooperation between downstream and upstream countries.

Many brand marketers and giant retailers, such as GAP, H\&M and Walmart, have no production facilities. They usually concentrate on product design, brand promotion and product distribution. The shipment of ready-to-use products from assemblers or original equipment makers to the home market of these lead firms of value chains is an indispensable step towards the realization of the value of brands and distribution networks. Walmart currently imported some US $\$ 49$ billion in goods from China in 2013 (Scott, 2015). If counted as a country, Walmart would be China's $8^{\text {th }}$ largest importing nation. The bilateral trade flows between China and the US resulting from the outsourcing activities of Walmart present a new type of cooperative relationship between exporters and importers, who are responsible for distinct but interlinked tasks in value chains.

Moreover, under GVCs, trade that used to be bilateral is now multilateral. The triangle trade formed by production networks in East Asia is a case in point. At the center of the triangle trade, China imports intermediate inputs from Japan, Taiwan, Korea, Singapore and other East Asian economies, assembles them into finished products, and eventually exports them to the US and European markets. The gross value of China's exports includes not only domestic value added but also the value added of other East Asian economies, and thus should be counted as exports of East Asian economies, not simply China's exports to these markets. Following the same logic, some part of the bilateral trade imbalance between China and the US is multilateral rather than bilateral. Clearly the source and destination markets of China's processing trade outline the operation of China-centered value chains at country level. About $80 \%$ of China's processing imports-necessary intermediate inputs of China's processing exports-originates in East Asian economies, while more than $70 \%$ of China's processing exports end up in US and European markets. As a result, China runs a large processing trade surplus with the US on the one hand and a significant trade deficit with Korea and Taiwan on the other. A 
substantial part of China's trade surplus with the US actually consists of transfers from other East Asian economies.

Given the complexity of trade relationships under GVCs, it is very costly to impose protection measures. Restrictions may hinder domestic firms' participation in GVCs and constrain their export capacities. If trade protection measures were imposed in a given country, both the consumers of the country and its producers would suffer. In addition, if tariff and non-tariff measures imposed by an individual country raised the cost of the final products, all countries involved in the value chains would be worse off. As bilateral trade relations have evolved into multilateral relations, and since the competitiveness of final products is now determined by combined national comparative advantage, unilateral actions may not be effective means of resolving bilateral trade imbalances.

\section{Measuring Trade in Value Added}

Conventional trade statistics measure the gross value of goods when they cross national borders. In the literature, economic interpretations of trade statistics implicitly assume that entire gross value is produced domestically by the exporting country. That assumption has dominated trade debates, negotiations and the evaluation of individual countries' export capacity. There is no doubt that that assumption flies in the face of the reality of value chain trade. As argued above, the value added of a product manufactured along a value chain is attributed not to a single country, but to all the countries taking part in that GVC. While products evolve along value chains from raw materials, to parts, to semi-finished to final products, value is continually being added by firms specializing in different chain segments and located in different countries. Therefore, the gross value of exports and imports consists of an aggregate of domestic value added and foreign value added.

Conventional trade statistics tend to exaggerate export volumes and provide misleading information on export capacity and comparative advantage. For example, although Chinese workers, specializing in assembly tasks, add a mere $\$ 6.5$ to the US\$178.96 manufacturing cost of a $3 G$ iPhone, under the current system of trade 
statistics, China is credited with value added of US\$178.96 whenever a 3G iPhone is shipped abroad. The export of 11.3 million iPhones to the US in 2009 resulted in a $\$ 1.9$ billion trade surplus for China. In fact, however, only $3.6 \%$ of the value originated in China, the rest being generated by Japan, Korea, Germany and other countries involved in the iPhone value chain (Xing and Detert, 2010).

iPhone trade is not an isolated case. On average, foreign value added constitutes more than $55 \%$ of China's high-tech exports, and more than $85 \%$ of processing exports with supplied materials (Xing, 2015). A recent study by UNCTAD (2013) shows that foreign value added accounted for $31 \%$ of the gross exports of developed economies, and $25 \%$ of those of developing economies, implying that double counting is a serious problem in current trade statistics, which fail to articulate the distribution of value added in exports over countries.

Exports play a critical role in driving economic growth. To accurately assess the contribution of exports to national income, it is essential to measure trade in terms of value added. International organizations such as OECD and WTO have begun research towards the construction of a trade in value added database. The preliminary results are available on the OECD website. The WTO also initiated the "made in the world" concept in response to the collapse of the concept of country of origin of manufacturing goods (Lamy, 2011). JETRO-IDE shows that if the value added approach were applied, the Sino-US trade surplus would be halved (IDEJETRO and WTO, 2012).

In addition, conventional trade statistics may distort the estimates of comparative advantage and misrepresent dynamic changes in export composition. Economists use revealed comparative advantage as a proxy of national comparative advantage. Since a substantial portion of foreign value added is embedded in exports, revealed comparative advantage computed with gross value of trade tends to overestimate an economy's comparative advantage in products and industries where imports constitute a significant portion of intermediate inputs. Trade statistics show that China is the world leading exporter of laptop computers, digital cameras, mobile phones and other ICT products; then clearly China should have revealed 
comparative advantage in all those products. However, given that foreign MNEs own the intellectual property such as the brands and key components of those products, and low-tech parts production and assembly are performed by Chinese workers, the assumption that China has comparative advantage in those products is false.

These odd trade phenomena, such as China's export of iPhones to the US and China's world leadership in high-tech exports, reflect improperly framed trade statistics which fail to identify sources of value added and cannot distinguish tasks from final products, and thus mistakenly suggest for example that everything shipped out of China was made there. This suggests that a value added (or task oriented) approach should be adopted for assessment of comparative advantage and dynamic changes in trade structures. Measuring trade in value added is imperative for accurate characterization of cross country distributions of whole value added of exports, for the purpose of identifying which countries have comparative advantage in which tasks, and the tracing of the roots of bilateral trade imbalances. This would serve to eliminate existing distortions and would present a more accurate picture of trade patterns and technology capacity across countries.

The inclusion of developing countries in GVCs enables firms in those countries to perform low skilled tasks within the manufacture of high-tech products. However, this does not necessarily mean that those firms have acquired the necessary skills, technology and production know-how required for the independent creation of those high-tech products. Regardless of the tasks performed, using final products as an indicator of the technological level of firms participating in GVCs is misleading and misrepresents technological advancement and the evolution of trade structures (Xing, 2014). This could be remedied by considering task intensity and share of value added in assessments. The governments of developing countries often adopt preferential policies and fiscal subsidies to promote high-tech industry. Those policies should target the firms that perform high-value added tasks and produce key components, not the assemblers.

\section{Weakened Linkages between Trade and Exchange Rates}


Exchange rates determine foreign goods prices in domestic currency, so they can influence consumer demand and trade flow. Conventional trade theory suggests that exchange rates play a central role in determining the competitiveness of a country in the world economy. If a country's currency appreciates, its exports become more expensive and as a result foreign demand decreases, while imports become cheaper and demand for them increases. All this would lead to a decrease in the country's trade surplus. This view of the interplay between exchange rates and trade implicitly assumes that the entire value-added of exports is produced domestically and thus all imports exclusively serve domestic consumption and investment. As argued above, the value added of products manufactured along GVCs cannot be attributed to any single country, but to all the countries involved in the process. Regardless of whether firms have monopolistic power and thus can engage in exchange rate pass-through, the currency appreciation of a single country can only affect the portion of value added generated in that country, which has a limited effect on the overall cost of products traded along value chains. In other words, GVCs mitigate elasticities of export and import demand to exchange rates. In the case of iPhone trade, if the Chinese yuan appreciated 50\% against the US dollar, the total manufacturing cost would increase by at most $\$ 3.25$ from the original $\$ 178.96$, not by the predicted $\$ 89.50$, because the appreciation of the yuan should only affect the costs incurred in China, and the foreign content embedded in the iPhone is unaffected by that appreciation. The economics literature and policy debates on the impact of exchange rates fail to distinguish fundamental differences between gross trade values and trade in value added. Furthermore, exchange rates of different countries usually do not move in the same direction. It is highly likely that, if the currency of the home country depreciated against the US dollar, the currencies of other countries along the relevant value chains would appreciate against the US dollar. The potential impact of home currency depreciation would be offset (and likely neutralized) by appreciation. Hence, assessment of the impact of exchange rates on value chain trade should focus on value added rather than gross trade value. It is essential to evaluate the combined effect of cross-country exchange rates, rather than movements of a single currency. 
In macroeconomic models, imports proxy domestic demand for foreign goods and services. Countries participating in global production networks need to import a large quantity of parts and components for the production of exports. The quantities of imports used as inputs of exports are actually determined by foreign demand, not domestic demand. In general, the appreciation of home country currency would not affect the purchasing power of foreign consumers. Imports used for producing exports do not respond in the conventional fashion to the movements of exchange rates. Classifying imports according to purpose is essential for accurate determination of the relationship between imports and exchange rates. Xing (2012) shows that given a $10 \%$ real appreciation of the yuan, China's processing imports would fall 5\%. Using Belgian firm-level data, Amiti et al. (2013) determined that exporters that import a large share of inputs pass on a much smaller share of exchange rate shocks to exports prices. They argue that movements in the value of a country's currency are positively correlated across its trade partners, and thus create a natural hedge against exchange rate movements and reduce the need for exporters to adjust their export market prices.

The International Monetary Fund (IMF) publishes the real effective exchange rates (REER) of all its member countries. REER is based on gross trade flows and consumer price indexes, which are not compatible with trade flows through vertical specialization. Bems and Johnson (2012) propose a value-added REER, in which the weights of trading partners are calculated as bilateral trade in value added. Value-added REER takes global value chains into account in its assessments of competitiveness; this suggests that value-added REER can be used as an alternative means of evaluating the impact of exchange rates on the comparative advantage of countries participating in global production networks. The IMF has begun research towards adjusting its REER with trade in value added.

\section{Rules of Origins and Value Chain Trade}


Rules of origin, the criteria for determining the national source of a product, are used in the implementation of trade measures and preferential treatment. Bilateral and multilateral free trade agreements apply rules of origin to determine which products are qualified for preferential treatment. In value chain trade, the country origins of goods have become blurred. For many manufactured products, it is almost impossible to identify a single country which accounts for $50 \%$ of total value added. Hence, it is now very challenging to clearly define country origin. The label "Made in China" attached to processing exports is often misleading, as more than $50 \%$ of their value added imported can be from abroad. In many cases, then, "Assembled in China" would be a more accurate description than "Made in China." That is why WTO Secretary General Pascal Lamy called for the use of the "Made in the World" concept (Lamy, 2011).

In practice, FTAs usually require a minimum of $40 \%$ domestic content for products to qualify for preferential treatment. Many firms participating in GVCs may not add more than $40 \%$ to the content of assembled products. Firms in developing countries rely mainly on their comparative advantage in low labor costs and thus specialize in low value added segments of GVCs. Domestic content of exports by firms in developing countries, in particular small and medium-sized enterprises, is generally less than $40 \%$. For example, it is estimated the domestic value added of China's processing exports with supplied materials is less than $15 \%$ (Xing, 2015). Requiring a high percentage of local value added in FTAs poses the risk of excluding the firms in the low value added segments of GVCs, thus depriving them of opportunities to benefit from trade liberalization, and in the long run undermining the overall welfare effect of FTAs. The agreement of Trans-Pacific Partnership (TPP) adopts a "yarn forward" rule of origin, which requires that textile and apparel products be made of yarns and fabrics of TPP countries for the benefits of the agreement. In other words, if textile producers of TPP countries want to take advantage of the agreement, the value added of their products should be $100 \%$ produced within TPP countries. Textile products represent the largest item of Vietnam's exports to the US. However, $60-70 \%$ of yarn and fabrics in Vietnam is imported from non-TPP members. If Vietnam's textile producers cannot use locally produced yarns and fabrics, or source 
from Japan, the US or other TPP countries, they will not be able to benefit from the agreement.

\section{The Delinking of Innovation and Job Creation}

The invention of the internal combustion engine, the train and the automobile created a huge number of jobs and greatly enhanced industrialization and urbanization in developed countries. Since globalization entered the second unbundling - the division of production processes worldwide and the global sourcing of inputs (Baldwin, 2011), the linkage between technological innovation and job creation has been weakened; now technological innovations may not necessarily generate significant domestic employment. In effect, the worldwide proliferation of GVCs has resulted in the geographic separation of product design and manufacturing, which in turn undermines the natural link between innovation and domestic employment. As MNEs - the global leaders of technological innovationincreasingly concentrate on their core competencies, such as research and development, product design, manufacture of key components and brand promotion, more and more general manufacturing and assembly tasks are outsourced to foreign countries, where cheap and low skilled workers perform basic tasks. Product design and invention require far fewer workers than the production of sufficient quantities of products to meet global market demand. Usually, a few hundred genius level scientists and engineers are sufficient to design new products. On the other hand, the manufacture of parts and components and their assembly into finished products for export to various countries can require millions of workers. The separation of product design and manufacturing undercuts the employment creation potential of innovation in local economies. Growth without employment creation is now common in developed countries. The trend of de-industrialization in previously industrialized countries is a consequence of the GVC approach.

In 1960, General Motors, Ford Motors and General Electric were the top employers in the US, providing American workers with 595,200, 260,000 and 260,600 jobs respectively (Cox et al, 2012). Today, Apple, which has a market value higher than the combined market value of those three American companies, employs about 
43,000 workers in the US, while its foreign subcontractors, who manufacture all of Apple"s i-products, employ about 700,000 workers. When President Obama asked Steve Jobs, "What would it take to make iPhones in the United States?", Jobs' reply was, "Those jobs aren't coming back" (Duhigg and Bradsher, 2012). One senior Apple executive stated that a shortage of qualified American workers was the major reason for outsourcing Apple's manufacturing work to China and other East Asian countries. Labor market mismatch may appear to be a reason for Apple's gradual evolution into a factoryless high-tech company, but using GVCs to maximize profits must be the fundamental force driving not only Apple but also many other MNEs to build value chains and outsource some activities abroad. In the process, developing countries, which have comparative advantage in labor-intensive tasks, benefit tremendously in terms of employment and industrialization. The "de-industrialization" process in developed countries is now associated with the progress of industrialization in developing countries (Saeger, 1997).

\section{GVCs and an Alternative Path to Industrialization}

A top development agenda item of low-income countries has always been the narrowing of the gap between them and developed countries and the pursuit of industrialization. Import substitution industrialization, the replacement of foreign imports with domestic production, dominated the development strategy of Latin American countries until 1990. The East Asian Miracle, marked by rapid industrialization and the successful transformation of the four Asian Tigers (Hong Kong, Singapore, South Korea and Taiwan) into advanced high-income economies, triggered the development strategy paradigm shift from import substitution to exportoriented industrialization, which promotes exports according to comparative advantage. In recent decades, the emergence of GVCs has revolutionized the nature and scope of export-oriented industrialization. The international division of labor in the world economy has evolved from the level of goods and industries to the more refined level of tasks. The fragmentation of production on a global scale provides ample opportunities for developing countries to participate in value chains and take advantage of their comparative advantage. Once integrated into GVCs, 
firms from developing countries can now access the world market via established distribution networks, benefit from the growth of high-tech markets regardless of their disadvantage in technological capacity, take advantage of the spillover of brands and the lower information costs of reverse engineering-and proceed to catch up.

To a large extent, new and fast growing markets are nurtured by technological innovation and the invention of products. Revolutionary innovations in information and communication technology (ICT) have given rise to a variety of new products, including laptop computers, smart phones and tablets, and thus dramatically increased consumer demand beyond the demand for traditional commodities. In 2012, ICT goods emerged as one of the top product groups traded globally. World imports of ICT goods rose to US $\$ 2$ trillion, about $11 \%$ of world merchandise trade, exceeding trade in agriculture and motor vehicles (UNCTAD, 2014). Most if not all of the intellectual property inherent in ICT products is owned by MNEs in developed countries. Unlike established MNEs, firms in developing countries have no comparative advantage in high-tech products, and thus are unlikely to be able to market products with their own intellectual property, or to compete with existing technology leaders. By specializing in low value added segments such as assembly and the production of low-tech components, they are able to join the value creation process of high-tech products and grow together with the lead firms. They can also enjoy spillover from globally recognized brands and intellectual property, which generally belong to the firms that direct value chains. Brands play a critical role in consumer purchasing decisions; demand for branded commodities tends to be stronger than that for non-branded goods. Consumers' brand preferences can be carried over to the demand for tasks performed by all firms in value chains. Whether they own the intellectual property rights of brands or not, all firms taking part in buyer-driven value chains can benefit from the brand orientation of consumers. In short, GVCs offer an alternative path for developing countries to enter the global market and achieve industrialization. 
A few Asian countries have successfully developed their industrial sectors through active participation in GVCs. The most noteworthy example is China, which has become the largest exporting nation in the world. The rapid growth and worldwide expansion of China's exports are the result not only of intrinsic comparative advantage, but also to a large extent of spillover from GVCs in terms of the brands, global distribution networks and technology innovations of lead firms (Xing, 2016). An export-oriented growth strategy and the influx of foreign direct investment contributed greatly to the integration of Chinese manufacturing with GVCs. By specializing in the low value added segments of GVCs, Chinese firms have been able to bundle low skilled labor services with globally recognized brands and advanced technology and sell them to global consumers, driving the growth of China's exports. Assembly is a low value added segment of ICT manufacturing, and thus suitable for China's comparative advantage in low skilled labor services. Many Chinese companies, both local and foreign invested, have plugged themselves into ICT GVCs by concentrating on assembly tasks, and as a result have gradually transformed Chinese manufacturing into the assembly center of the global ICT industry and the top exporter of digital cameras, smart phones and laptop computers. In terms of value added per unit product, assembly contributes the least among all the tasks in value chains. However, given the huge scale of the global market, the aggregate value added of assembled ICT products exported from China to foreign markets is enormous; China's processing exports are a pillar of its economic growth and employment.

Thailand's success in building its domestic automobile industry is an industryspecific case of achieving industrialization through GVC participation. With output of 1.5 million units in 2012, Thailand became the third largest commercial vehicle producer in the world, exporting automobiles, parts and accessories with a total value of $\$ 12.7$ billion, the largest among Thai exports. The opening of Thai commerce to foreign direct investment and the integration of local automobile sectors into global automobile value chains are the main reasons for Thailand's emergence as the auto export hub of ASEAN. After the Asian financial crisis, the Thai government fully liberalized foreign direct investment in the automotive sector 
by abolishing the existing local content requirement and permitting $100 \%$ foreign ownership. These new policy initatives have attracted massive inflows of foreign investment into the sector, in particular investment by Japanese automakers such as Toyota and Nissan. MNEs usually extend their value chains abroad through green field investment. Foreign automakers not only target the local market, but also use Thailand as a platform for automobile export in the region. Unlike many developing countries, Thailand has never had the explicit goal of developing a national car. This has indirectly encouraged local firms to specialize in segments consistent with their comparative advantage. Thailand's active participation in global automotive value chains has led over time to industrial upgrading and the subsequent deepening of the country's technological capabilities in the sector. Local content has reached 80 $90 \%$ of total value added for pickup trucks and $30-50 \%$ for passenger cars assembled in Thailand (Techakanont, 2014).

The successful experiences of China and Thailand indicate that the worldwide proliferation of value chains has lowered barriers and offered developing countries new opportunities to integrate their economies into the global market and thus benefit from globalization. To take advantage of GVCs, developing countries need industrial policy with four essential elements: the policy should focus on task capabilities rather than sectors or whole industries; assistance must be provided to domestic firms to systemically upgrade their capability and skills along value chains; relations with the lead firms governing GVCs must be nurtured so as to generate opportunities for participation in GVCs; and efficient infrastructure, including both transport logistics and ICT, must be established to ensure the smooth operation required by GVCs (i.e. industry policy needs to include investment in infrastructure (Kaplinsky, 2013)).

\section{Concluding Remarks}

International trade in manufactured products is now predominantly achieved through GVCs, which give rise to new opportunities for developing countries to participate in international markets and pursue industrialization. Value chain based trade has fundamentally changed the patterns of trade between developing and developed 
countries, extended bilateral trade balances into multilateral ones, weakened the nexus between trade balances and exchange rates, and delinked product inventions and domestic unemployment. The challenges associated with the emergence of GVCs require an understanding of modern international trade, which in turn calls for new modes of thinking and new theories. Focusing on production process segments of GVCs, rather than on entire industries, is a promising strategy for achieving export-oriented industrialization. 


\section{References}

Amiti, M, Itskhoki, O, and Konings, J. (2013). Why do large movements in exchange rates have small effects on international prices? VOXEU 19.

Bald, R. (2011). Trade and industrialization after globalization's $2^{\text {nd }}$ unbundling: how building and joining a supply chain are different and why it matters. NBER working paper No. 17716.

Bems, R. and Johnson, R. (2012) Value-added exchange rates. VOXEU, 6. Dec. Cox, A. et al (2012). The iPhone economy. New York Times, Jan. 21.

Duhigg, C. and Bradsher, K. (2012). How the US lost out on iPhone work. New York Times, Jan. 21.

Gereffi, G and Karina, F. (2011). Global value chain analysis: a primer. Center on Globalization, Governance and Competitiveness, Duke University.

Gereffi, G. (1999). International trade and industrial upgrading in the apparel commodity chain. Journal of international Economics, Vol. 48: 37-70.

Grossman G.M. and Rossi-Hansberg, E. (2008). Trading tasks: a simple theory of offshoring. American Economic Review, 98(5): 1978-1997.

IDE-JETRO and WTO (2012). Trade patterns and Global Value Chains in East Asia, Tokyo: IDE-JETRO.

Kaplinsky, R. (2013). "Shudder: the challenges to "industrial policies" in the early 21 century in low and middle income economies," Development of Policy and Practice, the Open University.

Lamy, P. (2011). "Made in China tell us little about global trade," Financial Times, Jan. 24, 2011.

Meri, T. (2009). China passes the EU in high-tech exports. Science and Technology, Eurostat Statistics in focus.

OECD and WTO (2013). Trade in Value-Added: Concepts, Methodologies and Challenges. Joint OECD-WTO Note. http://www.oecd.org/sti/ind/49894138.pdf

Saeger, S.S. (1997). "Globalization and Deindustrialization: Myth and Reality in the OECD," Weltwirtschaftliches Archiv, Vol. 133(4): 579-607.

Scot, E. R. (2015). "A conservative Estimate of the Wal-mart effect," Economic Policy Institute. 
Techakanont, $\mathrm{T}$ (2014). Role of production networks and global chains in the development of automobiles in Thailand. Presentation at the ADBI/RSIS Conference: Trade in Value-Added, Global Value Chains and Development Strategy, Singapore, 2014.

UNCTAD. (2013). World Investment Report 2013. Geneva: United Nations Publication.

US. Census Bureau (2011), "U.S. Trade with China in Advanced Technology Products,"

http://www.census.gov/foreigntrade/statistics/product/atp/2010/12/ctryatp/atp5700.htm

Xing, Y. (2016). "Global value chains and China's exports to high-income countries," International Economic Journal, Vol. 30(2): 191-203

Xing, Y. (2015). "Estimating the upper limits of Value added in the PRC's processing exports," in Uncovering Value added in Trade: New Approaches to Analyzing Global Value Chains, Yuqing Xing (ed.), page 61-80. .

Xing, Y. (2014). "China's high-tech exports: myth and reality," Asian Economic Papers, Vol. 13(1):109-123.

Xing, Y. (2012). "Processing trade, exchange rates and China's bilateral trade balances," Journal of Asian Economics 23(5): 540-547.

Xing, Y and N. Detert (2010). "how the iPhone widens the US trade deficit with the PRC," ADBI working paper No. 257, Tokyo: Asian Development Bank Institute. 